\title{
TINGKAT KEPUASAN MASYARAKAT TERHADAP PENDAFTARAN ONLINE PADA APLIKASI MOBILE JKN
}

\author{
Herlinawati ${ }^{1)}$, Lilis Banowati ${ }^{2)}$, Devi Revilia ${ }^{3)}$ \\ ${ }^{1,2,3}$ Sekolah Tinggi Ilmu Kesehatan Cirebon \\ Emai : linacirebon@gmail.com
}

Diterima: Mei 2021, Diterbitkan: Juni 2021

\begin{abstract}
ABSTRAK
Pandemi Covid-19 yang terjadi diseluruh negara termasuk Indonesia, membuat BPJS Kesehatan harus beradaptasi dengan pola layanan baru yang benar-benar memperhatikan protokol kesehatan tanpa mengurangi kualitas pelayanan yang selama ini sudah berjalan baik. Mobile JKN merupakan salah satu alternatif paling efektif yang saat ini bisa dijalankan oleh BPJS Kesehatan untuk tetap bisa melayani dalam kondisi seperti ini. Penelitian ini bertujuan untuk mengetahui tingkat kepuasan masyarakat terhadap pendaftaran online BPJS Kesehatan pada aplikasi mobile JKN pada masa Pandemi Covid 19. Penelitian ini merupakan penelitian deskriptif. Populasi adalah seluruh peserta BPJS di Kabupaten Cirebon Tahun 2021 yang telah mendowload aplikasi mobile JKN. Populasi sejumlah 129.357 peserta. Besar sampel menggunakan rumus Slovin di dapatkan 100 responden diambil dengan teknik accidental sampling. Analisa data menggunakan analisa univariat dalam bentuk persentase. Hasil penelitian menunjukkan sebagian besar (73\%) responden merasa puas terhadap pendaftaran online BPJS Kesehatan pada aplikasi Mobile JKN pada masa pandemi Covid-19. Di harapkan kepada BPJS Kesehatan Cabang Kabupaten Cirebon untuk melakukan sosialisasidan demonstrasi melalui media cetak, elektronik, dan radio lebih intensifi mengenai penggunaan aplikasi Mobile JKN.
\end{abstract}

Kata Kunci: Kepuasan, Aplikasi Mobile JKN

\begin{abstract}
ABSTRAK
The COVID-19 pandemic which occurs in all countries including Indonesia has forced Administrative Body for Health (BPJS) to adapt to new service patterns that continuously pay attention to health protocols without reducing the quality of service that has been running well. Mobile National Health Insurance $(J K N)$ is one of the most effective alternatives that BPJS can currently use to continue its services in the current condition. This study aims to determine the level of community satisfaction with BPJS online registration on the mobile JKN application during the COVID-19 Pandemic. This was a descriptive study. The population was all BPJS participants in Cirebon District in 2021 who have downloaded the JKN mobile application as many as 129,357 participants. Determination of sample size used the Slovin formula which obtained 100 respondents taken by accidental sampling technique. Data were analyzed using univariate analysis in the form of a percentage. The results showed that most respondents (73\%) were satisfied with the BPJS online registration on the Mobile JKN application during the COVID-19 pandemic. It is expected that Administrative Body for Health of Cirebon District Branch will conduct socialization and demonstrations through print, electronic and radio media to be more intensified regarding the use of the Mobile JKN application.
\end{abstract}

Keywords: Satisfaction, JKN Mobile Application

\section{PENDAHULUAN}

Penyebaran virus Corona di Indonesia yang semakin meningkat, mendesak pemerintah pusat maupun pemerintah daerah mengambil langkah preventif untuk memutus rantai penularan Corona. Salah satunya adalah dengan memaksa agar setiap masyarakat Indonesia melakukan pembatasan kerumunan dan menerapkan protokol kesehatan melalui 
siaran pers Direktur Jenderal WHO, Dr. Tedros Adhanom Ghebreyesus, menyampaikan penetapan Covid-19 sebagai pandemi global (Menteri Kesehatan Republik Indonesia, 2020).

Sejak awal Bulan Maret 2020, berbagai kebijakan telah dikeluarkan oleh pemerintah pusat dan daerah. Mulai dari membatasi hubungan sosial (social distancing), menghimbau untuk bekerja di rumah (work from home) dan menghimbau masyarakat untuk tetap di rumah serta mengurangi aktivitas ekonomi di luar rumah. Akhir Maret 2020 kebijakan pemerintah bukan hanya social distancing tapi dilanjutkan dengan Physical Distancing serta menetapkan Pembatasan Sosial Berskala Besar (PSBB). Pelayanan publik dituntut untuk memberikan kepastian pelayanan, kejelasan informasi pelayanan, dan responsivitas pelayanan dan pelayanan publik harus dapat dirasakan oleh lapisan masyarakat khususnya kelompok rentan. Dengan banyaknya instansi penyelenggara layanan publik yang membatasi layanan, menginisiasi layanan online bahkan sampai meniadakan pelayanan sementara, menjadi satu fenomena yang harus dilakukan (Ombudsman, 2020).

Salah satu jenis pelayanan yang terkena dampak pada masa pandemik ini adalah pelayanan BPJS (Badan Penyelenggara Jaminan Sosial) Kesehatan. BPJS Kesehatan berkomitmen memberikan pelayanan terbaik bagi masyarakat baik dalam hal pelayanan kesehatan maupun pemberian informasi kepada masyarakat Indonesia. Pandemi Covid-19 yang terjadi diseluruh negara termasuk Indonesia, membuat BPJS Kesehatan harus beradaptasi dengan pola layanan baru yang benar-benar memperhatikan protokol kesehatan tanpa mengurangi kualitas pelayanan yang selama ini sudah berjalan baik (Kesehatan, 2020).

BPJS Kesehatan memberikan inovasi pengembangan aplikasi Mobile JKN yang berguna untuk mempermudah pelayanan Jaminan Kesehatan Nasional-Kartu Indonesia Sehat. Mobile JKN merupakan salah satu alternatif paling efektif yang saat ini bisa dijalankan oleh BPJS Kesehatan untuk tetap bisa melayani dalam kondisi seperti ini. Hal ini ditujukan untuk mengurangi angka penularan Covid-19 di lingkungan Kerja Kantor BPJS Kesehatan dan di masyarakat (Kesehatan, 2020).

Mobile JKN bertujuan agar masyarakat dapat menikmati layanan dengan cepat. Aplikasi ini dapat digunakan dimana saja kapanpun tanpa batasan waktu (self service) Inovasi pelayanan yang dilakukan oleh BPJS Kesehatan diharapkan dapat memenuhi kepuasan pelanggan sebagai peserta BPJS Kesehatan. Kepuasan merupakan perbedaan antara harapan dan unjuk kerja yang diterimanya (Felita et al., 2018). Untuk mengukur kepuasan pelanggan ada tiga aspek penting yang saling berkaitan, yaitu pertama apa yang akan diukur, bagaimana metode pengukurannya, dan bagaimana skala pengukurannya (Harfika \& Abdullah, 2017).

Pada penelitian yang dilakukan di China menjelaskan bahwa banyak tantangan adopsi dalam penerapan Mobile health. Yu, et al (2016) menjelaskan bahwa aplikasi harus sepenuhnya terintegrasi kedalam alur kinerja klinis dan penilaian dalam perawatan pasien sambil menawarkan administrasi yang mudah dan memfasilitasi komunikasi antara layanan kesehatan. Satu penelitian mengenai kualitas dan kesuksesan sistem informasi kesehatan bernama Homedika. Homedika hadir sebagai wirausaha sosial berbasis teknologi yang menghubungkan tenaga kesehatan dan fasilitas kesehatan dengan masyarakat untuk memberikan berbagai layanan kesehatan. Hasil analisis yang diperoleh dalam penelitian ini mengatakan penilaian kualitas oleh responden masuk dalam ketegori cukup (Felita et al., 2018). 
Setiap tahun, jumlah masyarakat yang telah menjadi peserta Jaminan Kesehatan Nasional terus bertambah. Berdasarkan data yang didapat dari Humas BPJS Indonesia didapat data sebanyak 223 juta jiwa pada 2018, menjadi 235.1 juta jiwa pada 2019 dan mencapai 257,5 juta jiwa atau seluruh penduduk Indonesia pada 2020. Begitu juga data peserta BPJS di Kabupaten Cirebon (2020) juga mengalami peningkatan yang signifikan dari sebanyak 2.073.642 tahun 2019 menjadi 2.122.490 jiwa atau sebesar 96,05\% dari jumlah penduduk Kabupaten Cirebon sebanyak 2.209.870 jiwa pada tahun 2020. Yang terdaftar sebagai peserta Jaminan Kesehatan Nasional di wilayah Kabupaten Cirebon 2.030.855 jiwa tahun 2021, dan yang sudah download aplikasi Mobile JKN 129.357 jiwa $(0,064 \%)$ (Cirebon, 2020).

Berdasarkan hasil studi pendahuluan yang dilakukan peneliti pada 10 peserta yang berkunjung ke kantor BPJS Kesehatan Kabupaten Cirebon didapat hasil 3 peserta $(30 \%)$ tidak mengetahui tentang aplikasi Mobile JKN. 5 peserta lainnya (50\%) lebih memilih untuk datang langsung ke kantor BPJS Kesehatan daripada memakai aplikasi Mobile JKN dengan alasan kurang paham dengan bahasa yang disampaikan dalam aplikasi dan respon yang lama dari admin yang ada di aplikasi Mobile JKN dan 2 peserta yang lain $(20 \%)$ mengatakan berasal dari daerah yang susah mendapatkan sinyal.

Penelitian ini bertujuan untuk mengetahui tingkat kepuasan masyarakat terhadap pendaftaran online BPJS Kesehatan pada aplikasi Mobile JKN pada masa Pandemi Covid-19.

\section{METODE PENELITIAN}

Jenis penelitian ini menggunakan jenis penelitian deskriptif (Notoatmodjo, 2014) Populasi penelitia adalah seluruh peserta BPJS Kesehatan di Kabupaten Cirebon yang sudah download aplikasi
Mobile JKN yang berjumlah 129.357 orang pada periode bulan Februari 2021.

Besar sampel pada panelitian ini dilakukan dengan menggunakan penggunaan rumus slovin di dapatkan 100 Sampel, pengambilan sampel menggunakan teknik accidental kepada responden yang datang ke kantor BPJS dan yang berada di RS wilayah Kabupaten Cirebon dengan kriteria inklusi peserta yang sudah pernah menggunakan aplikasi mobile JKN dan bersedia menjadi responden. Instrumen penelitian menggunakan kuesioner, pengumpulan data dilakukan dengan wawancara kepada responden.

Hasil uji validitas dan reliabilitas yang telah dilakukan menunjukan nilai corrected item total correlation pada seluruh pernyataan kepuasan pelanggan tersebut valid. Sedangkan hasil reliabilitas kepuasan pelanggan diperoleh nilai Cronbach's Alpha $=0,9737 \quad(>0,6)$, sehingga kuesioner secara keseluruhan dianggap reliabel.

Analisa univariat dilakukan terhadap tiap variabel dari hasil penelitian. Analisa univariat digunakan untuk menampilkan distribusi frekuensi variabel. Lokasi penelitian di Wialyah Kabupaten Cirebon

\section{HASIL PENELITIAN DAN PEMBAHASAN}

Hasil Penelitian dari 10 item pertanyaan yang mengukur varibel kepuasan adalah sebagai berikut:

Tabel 1

Distribusi Frekuensi jawaban responden dari 10 item pertanyaan yang mengukur kepuasan

\begin{tabular}{clrcr}
\hline No & \multicolumn{2}{c}{ Item Pertanyaan } & \multicolumn{2}{c}{ Puas } \\
\cline { 3 - 5 } & & $\mathrm{N}$ & $\%$ \\
\hline 1 & $\begin{array}{l}\text { Membantu } \\
\text { administrasi sehingga }\end{array}$ & $\begin{array}{l}\text { kegiatan } \\
\text { tidak ke }\end{array}$ & 92 & 92 \\
kantor BPJS & $\begin{array}{l}\text { Keluhan langsung di proses } \\
\text { dengan cepat }\end{array}$ & 80 & 80 \\
3 & $\begin{array}{l}\text { Prosedur mudah saat } \\
\text { menggunakan mobile JKN }\end{array}$ & 96 & 96
\end{tabular}




\begin{tabular}{clll}
4 & $\begin{array}{l}\text { Aplikasi berfungsi dengan baik } \\
5\end{array}$ & 87 & 87 \\
Akses aplikasi mobile JKN & 90 & 90 \\
tidak memerlukan waktu lama & & \\
6 & $\begin{array}{l}\text { Proteksi dan kerahasiaan data } \\
\text { terjaga }\end{array}$ & 94 & 94 \\
7 & $\begin{array}{l}\text { Penggunaan aplikasi dapat } \\
\text { menghemat biaya }\end{array}$ & 99 & 99 \\
8 & $\begin{array}{l}\text { Aplikasi mobile JKN mudah } \\
\text { dipahami }\end{array}$ & 75 & 75 \\
9 & $\begin{array}{l}\text { Fitur Aplikasi lengkap sesuai } \\
\text { dengan kebutuhan }\end{array}$ & 70 & 70 \\
10 & $\begin{array}{l}\text { Design menarik dan infromatif } \\
87\end{array}$ & 87 \\
\hline
\end{tabular}

Tabel 1 menunjukkan bahwa 92\% responden merasa puas karena dapat membantu kegiatan admisntrasi sehingga tidak datang ke kantor BPJS, 80\% menyatakan puas karena keluhan langsung di proses dengan cepat, $96 \%$ puas karena prosedur menggunakan aplikasi mudah, $87 \%$ merasa puas karena aplikasi berfungsi dengan baik, $90 \%$ puas karena akses aplikasi tidak memerlukan waktu yang lama, 95\% puas karena proteksi dan kerahasiaan data terjaga, 99\% puas karena merasa penggunaan aplikasi dapat menghemat biaya, $75 \%$ puas karena mudah menggunakan aplikasi, 70\% merasa puas terhadap kelengkapan fitur yang ada pada aplikasi dan 87\% merasa puas karena design menarik dan aplikatif.

Responden menyatakan puas karena keluhan langsung di proses dengan cepat dan puas karena prosedur menggunakan aplikasi mudah, hal ini sejalan dengan penelitian Jihan Natasha (2019) bahwa pelayanan yang tanggap, cepat dalam menanggapi keluhan pelanggan akan memberikan kepuasan kepada pasien (Natassa \& Dwijayanti, 2019). Selanjutnya responden merasa puas karena aplikasi berfungsi dengan baik, puas karena mudah menggunakan aplikasi, dan puas karena fitur yang ada pada aplikasi lengkap, hal ini sejalan dengan penelitian Hermasyah (2019) bahwa keadaan fisik fasilitas dalam penelitian ini di analogikan aplikasi dan kelengkapan fitur aplikasi mobile JKN memiliki pengaruh terhadap kualitas pelayanan, semakin baik fasilitas maka akan memberikan kepuasan (Hermansyah et al., 2019).

Hasil penelitian dari 10 item pertanyaan tentang mobile JKN, pada masing-masing item pertanyaan menunjukkan sebagian besar $(>75 \%)$ responden merasa puas dengan mobile JKN, mulai dari penggunaan aplikasi, penanganan terhadap keluhan, prosedur, waktu penggunaan, proteksi kerahasiaan data, biaya penggunaan serta design yang menarik dan infromatif. Sesuai dengan penelitian lain yang menunjukkan bahwa kepuasan peserta PBJS di pengaruhi oleh kualitas layanan mobile JKN seperti kecepatan proses penanganan peserta, pengaduan keluhan dan penanganan lebih mudah dan cepat, kemudahan pelanggan dalam mengakses aplikasi, mobile JKN dapat berfungsi dengan baik dan akurat (Komala \& Firdaus, 2020)

Pada item pertanyaan mengenai kelengkapan fitur pada aplikasi masih ada $30 \%$ responden yang merasa tidak puas karena fitur belum sesuai yang dibutuhkan hal ini sejalan dengan penelitian Nur Annisa (2020) yang menunjukkan bahwa tingkat usability yang ada pada aplikasi masih rendah dan belum sepenuhnya memenuhi kepuasan pengguna aplikasi, tingkat usability adalah tingkat kualitas dari suatu sistem yang digunakan sebagai alat bantu yang digunakan untuk menyelesaikan tugas (Annisa et al., 2020).

Pada item pertanyaan kemudahan dalam memahami penggunaan aplikasi menunjukkan bahwa $25 \%$ responden belum merasa puas. Studi DeLone dan McLean (2015) mengusulkan model untuk mengukur keberhasilan sistem informasi. Dalam model modifikasi DeLone dan McLean tantangan yang paling umum untuk solusi Mobile health adalah penerimaan kualitas yang terdiri dari tiga komponen: kualitas sistem, kualitas informasi dan kualitas pelayanan. Masingmasing harus terpisah karena mempengaruhi kepuasan pengguna yang 
mendukung keberhasilan implementasi sistem informasi yang digunakan.

Selanjutnya pengukuran variabel tingkat kepuasan di dapatkan hasil sebagai berikut:

Tabel 2

Gambaran tingkat kepuasan masyarakat terhadap pendaftaran online BPJS

Kesehatan pada aplikasi Mobile JKN pada masa pandemi Covid-19

\begin{tabular}{|c|c|c|c|}
\hline $\begin{array}{l}\mathbf{N} \\
\mathbf{0}\end{array}$ & $\begin{array}{l}\text { Tingkat } \\
\text { Kepuasan }\end{array}$ & $\begin{array}{l}\text { Frekuensi } \\
\text { (f) }\end{array}$ & $\begin{array}{c}\text { Persentase } \\
(\%)\end{array}$ \\
\hline 1 & Tidak Puas & 27 & 27 \\
\hline 2 & Puas & 73 & 73 \\
\hline \multicolumn{2}{|c|}{ Jumlah } & 100 & 100,0 \\
\hline
\end{tabular}

Berdasarkan hasil penelitian dari 100 responden didapatkan hasil sebagian besar responden $(73 \%)$ merasa puas terhadap pendaftaran online BPJS Kesehatan pada aplikasi Mobile JKN pada masa pandemi Covid-19.

Responden yang sebagian besar merasa puas dimungkinkan karena semakin gencarnya sosialisasi yang diberikan oleh BPJS Kesehatan terhadap penggunaan aplikasi Mobile JKN. Sejalan dengan penelitian Andi Saryoko (2019) bahwa masyarakat meras puas dengan adanya aplikasi mobile JKN dan dapat memenuhi harapan pengguna.

Aplikasi Mobile JKN merupakan aplikasi yang didesain oleh BPJS Kesehatan untuk memberikan kemudahan akses dan kenyamanan bagi peserta Jaminan Kesehatan Nasional-Kartu Indonesia Sehat. Aplikasi ini lengkap memuat informasi seputar Program Jaminan Kesehatan Nasional-Kartu Indonesia Sehat hingga bisa digunakan untuk pendaftaran peserta, merubah data peserta, serta mengecek iuran. Peserta bisa dengan leluasa memanfaatkan aplikasi ini untuk mengurus kepesertaan Jaminan Kesehatan Nasional-Kartu Indonesia Sehat tanpa harus datang ke kantor cabang BPJS Kesehatan (Kesehatan, n.d.).
Terdapat $27 \%$ Responden yang tidak merasa puas dan merasa lebih mudah datang langsung ke kantor BPJS untuk melakukan pendaftaran secara offline.. Hasil penelitian ini sejalan dengan penelitian Pratiwi Hanjani Putri dengan judul analisis penerimaan pengguna terhadap aplikasi mobile JKN Dengan menggunakan model unified theory of acceptance and use of technology atau UTAUT. Hasil penelitian didapatkan bahwa sebanyak $57 \%$ responden merasa terbantu dengan adanya aplikasi Mobile JKN namun sisanya sebanyak $43 \%$ tidak menerima aplikasi tersebut.(Pratiwi Hanjani Putri, 2019)

Responden merasa tidak puas terhadap pendaftaran online BPJS Kesehatan pada aplikasi Mobile JKN pada masa pandemi Covid-19 disebabkan masih gagap teknologi, kurang memahami penggunaan aplikasi, masih banyaknya NIK yang belum online dengan Disdukcapil, peserta diharuskan datang ke Disdukcapil untuk mengupdate NIK tersebut dan baru bisa di daftarkan online pada aplikasi Mobile JKN. Penyebab lain adanya signyal dari internet, sehingga peserta beranggapan kendala tersebut terletak pada aplikasi nya maupun kepada keterlambatan admin dalam melayani peserta. Ada yang berpendapat bahwa kurangnya sosialisasi dari pemerintah maupun BPJS Kesehatan tentang penggunaan aplikasi Mobile JKN sedangkan masayarakat Kabupaten Cirebon sebagian besar masih awam dalam penggunaan aplikasi berbasis handphone atau internet.

Sehingga dapat disimpulkan bahwa aplikasi Mobile JKN dapat membantu responden dalam mendapatkan layanan dari BPJS Kesehatan dan pengguna aplikasi BPJS Kesehatan menerima dengan adanya aplikasi Mobile JKN.

\section{SIMPULAN}

Peserta sebagian besar merasa puas terhadap pendaftaran online BPJS 
Kesehatan pada aplikasi Mobile JKN pada masa pandemi Covid-19. Peserta yang tidak puas di sebabkan karena masih gagap teknologi, belum memahami dalam penggunaannya dan fitur masih dianggap belum lengkap untu memenuhi sesuai kebutuhan peserta.

\section{UCAPAN TERIMKASIH}

Penelitian ini dapat terlaksana dengan bantuan berbagai pihak. Oleh karena itu peneliti dengan sepenuh hati menyampaikan rasa terima kasih kepada seluruh civitas akademika STIKe Cirebon.

\section{DAFTAR PUSTAKA}

Annisa, N., Pradana, D. S., \& Suharso, W. (2020). Evaluasi Aplikasi Mobile Jaminan Kesehatan Nasional (JKN) di Kota Malang Ditinjau Dari Aspek Usability. Jurnal Repositor, 2(12), 1689.

https://doi.org/10.22219/repositor.v2i 12.511

Buzin, C. H., Dewhurst, S. A., \& Seecof, R. L. (1978). Temperature sensitivity of muscle and neuron differentiation in embryonic cell cultures from the Drosophila mutant, shibirets1. Developmental Biology, 66(2), 442456. https://doi.org/10.1016/00121606(78)90250-6

Cirebon, B. C. K. (2020). Laporan Tahun 2020.

Felita, C., Alimah, N., Herlambang, A. D., \& Wijoyo, S. H. (2018). Kualitas dan Kesuksesan Implementasi Sistem Informasi Kesehatan dengan Menggunakan Model Unified Theory of Acceptance and Use of Technology dan Model Delone and Mclean. Jurnal Pengembangan Teknologi Informasi Dan Ilmu Komputer (J-PTIIK) Universitas Brawijaya, 2(12), 63866390.

Harfika, J., \& Abdullah, N. (2017). Pengaruh Kualitas Pelayanan Dan
Fasilitas Terhadap Kepuasan Pasien Pada Rumah Sakit Umum Kabupaten Aceh Barat Daya. Balance, XIV(1), 44-56. file:///E:/SEMESTER 6/SINTA KEPERCAYAAN, FASILITAS/FASILITAS (9).pdf

Hermansyah, H., Darmana, A., \& Nur'aini, N. (2019). Analisis Faktor Yang Memengaruhi Kualitas Pelayanan Kesehatan Dengan Metode Servqual Di Puskesmas Wilayah Kerja Dinas Kesehatan Aceh Timur Tahun 2018. Health Care: Jurnal Kesehatan, 8(1), 58-69.

https://doi.org/10.36763/healthcare.v8 i1.32

Kesehatan, B. (2020). Akses pelayanan dalam Genggalam: BPJS kesehatan luncurkan aplikasi PANDAWA. Retrieved February 1, 2021, from https://www.bpjskesehatan.go.id/bpjs/ index.php

Komala, R., \& Firdaus, A. (2020). Analisis Kualitas Layanan Mobile Jkn Terhadap. Jurnal Ilmu Manajemen Dan Bisnis Islam, 6(2), 188-199.

Menteri Kesehatan Republik Indonesia. (2020). KMK Nomor Hk.01.07/Menkes/328/2020 Tentang Panduan Pencegahan Dan Pengendalian Corona Virus Disease 2019 (Covid-19) Di Tempat Kerja. Menteri Kesehatan Republik Indonesia, 2019, 1-207.

Natassa, J., \& Dwijayanti, S. S. (2019). Hubungan Mutu Pelayanan Dengan Kepuasan Pasien BPJS Kesehatan Di Unit Rawat Inap RSUD Tengku Rafi'an Kabupaten Siak. Health Care: Jurnal ..., December 2017. http://jurnal.payungnegeri.ac.id/index. $\mathrm{php} /$ healthcare/article/view/52

Notoatmodjo, S. (2014). Metodologi Penelitian Kesehatan. Rineka Cipta.

Ombudsman. (2020). Berita - Ombudsman RI. In 2020. https://www.ombudsman.go.id/news/r /praktek-maladministrasi-yang-terus- 
berulang-dalam-penyelenggaraanpenerimaan-peserta-didik-baru-ppdbtahun-2017

Pemerintah upayakan Universal Health Coverage bagi Masyarakat Indonesia - Sehat Negeriku. (n.d.). https://sehatnegeriku.kemkes.go.id/ba $\mathrm{ca} / \mathrm{umum} / 20201212 / 0135971 /$ pemerin tah-upayakan-universal-healthcoverage-bagi-masyarakat-indonesia/ Pratiwi Hanjani Putri. (2019). Analisis penerimaan pengguna terhadap aplikasi mobile JKN dengan menggunakan model unified theory of accptance and use of tecchnology atau UTAUT. Universitas Islam Negeri Syarif Hidayatullah Jakarta.
Saryoko, A., Hendri, H., \& Sukmana, S. H. (2019). Pengukuran Layanan Pada Aplikasi Mobile JKN Menggunakan Metode Servqual. Paradigma - Jurnal Komputer Dan Informatika, 21(2), 157-166. https://doi.org/10.31294/p.v21i2.5412

Yu, P., Wu, M. X., Yu, H., \& Xiao, G. Q. (2006). The challenges for the adoption of m-health. 2006 IEEE International Conference on Service Operations and Logistics, and Informatics, SOLI 2006, 181-186. https://doi.org/10.1109/SOLI.2006.23 5545 